the restructuring of the research enterprise (see page 383), but there is still a long way to go. It is a pity that the reconstitution of the Russian Academy of Sciences in the past few weeks has not produced the tighter organization that circumstances require. The problem of the relationship between research and the universities - or the general lack thereof - also deserves attention. It is tempting to suppose that the middle of an economic crisis is not the time at which to embark on the long-term institution-building that will eventually be necessary. But this, surely, is just the time for planning the more creative relationship between the universities and research that is needed. Crises like that now in Russia are not just depressing times but are opportunities as well.

\section{An obdurate recession}

THE finance ministers of the seven richest nations of the world (called G7) seem to have held a meeting bordering on the complacent in New York last weekend. Their purpose was to "intensify their cooperative efforts to strengthen world economic growth". But the finance ministers, who were accompanied by their central bankers, seem as puzzled as the next man or woman about the causes of an obdurate recession. And they seem to have found no recipe for restimulating growth, except the decision that each member of the group will now aim, in necessarily different ways, at "sustainable growth with price stability". It is thus when petty criminals promise the magistrates who let them off lightly that they will do better in future.

As economic recessions go, the present (which set in a year ago) is not especially severe. Gross domestic product in some G7 countries has fallen by a few per cent, but in others (Germany and Japan for example) it is merely that the previous rate of growth has not been sustained. And whether the present downturn is essentially different from its predecessors remains a matter for conjecture. It is worrying that, both in the United States and Britain, signs of improvement have proved to herald a false spring. Last week's unemployment figures in the United States showed an unexpected increase when the government had been expecting (not to say hoping) that they would go the other way. None of this should surprise the finance ministers and central bankers of G7. It is not, after all, as if the world's financial system was in such good shape before the recession began. Among other things, it followed a long period in which bank and other financial institutions reported huge losses, first on loans to developing countries, then nearer home. Seemingly paper transactions, such happenings take money out of the system - witness the now-greater caution of most banks. For a time, impoverishment may have been concealed by the funds injected into the system to offset the supposed deflationary consequences of the stock-market crash of October 1987. When governments then took up the battle against inflation by means of high interest rates, two deflationary influences were brought together.

Since then, there has been a steady stream of bank and company failures adding to the spread of a general sense of impoverishment. When people see assets disappearing, it is only natural that they should spend less freely, and save instead. What with mounting fears of unemployment, and often the reality of it, there is every chance that people's attitudes towards the use of money have shifted substantially, perhaps permanently, in spendthrift countries such as Britain and the United States. Even if the banks would let them borrow, they are disinclined to spend. That is a prospect G7 should have reckoned with last weekend. So is the inevitable diversion of funds to Eastern Europe and further east.

So what, if anything, could get growth moving again? The answer is buried in the G7 statement put out from New York - a successful conclusion of the negotiations of the new deal under the General Agreement on Tariffs and Trade (GATT). The consequences could be apparent by the summer. By securing the more economic distribution of goods and (on this occasion) some services, many new suppliers would enjoy a greater sense of being rich, as would the customers for their goods, who would be paying lower prices for them. Of all the remedies for recession considered by $\mathrm{G} 7$, only a deal on trade can break the logjam. The group should have said so, and then have pinned the blame for impending failure on the European Communities' backwardness on agriculture.

\section{Setting priorities}

THROUGHOUT the world where government budgets are constrained by recessionary pinch, it is necessary to establish priorities in science as in other areas of public life. It is not enough to say that science is important; it is necessary to acknowledge that some research may be of greater importance (or value) than others.

In the United States, where president George Bush has just released his budget plans for the 1992 fiscal year, some scientific groups are trying to lead the way to a structure for setting priorities within science. For this, consensus within the affected community is required. The National Research Council has just taken a (modest) step with a report on space that says why it is important for scientists to set priorities (if they do not someone else will) but leaves actual priority-setting to a future committee.

The US National Institutes of Health is also getting into the priority setting business with a 'strategic plan' (whose details will be announced next week) that calls upon biomedical researchers to agree that funds for some areas should grow at a rate that is higher than others. The pretence that this does not happen already should give way to a more realistic view of the world of science funding. Setting priorities may be difficult (if for no other reason than offending one's colleagues) but in the interests of science itself it must be done. Efforts to set priorities should be supported, or at least viewed with an open mind. 